\title{
Some thoughts on \\ the conventional alteration of rhythm ${ }^{1}$
}

\author{
Alexei A.Panov ${ }^{a}$, Ivan V.Rosanoff ${ }^{a, b}$ \\ a Saint Petersburg State University, \\ 7-9, Universitetskaya nab., St. Petersburg, 199034, Russian Federation \\ b Saint Petersburg Rimsky-Korsakov State Conservatory, \\ 3, Teatralnaya square, St. Petersburg, 190000, Russian Federation
}

For citation: Panov A. A., Rosanoff I. V. Some thoughts on the conventional alteration of rhythm. Vestnik of Saint Petersburg University. Arts, 2018, vol. 8, issue 2, pp. 195-213. https://doi.org/10.21638/11701/ spbu15.2018.203

The article is dedicated to the problem of terminology concerning the main forms of the conventional rhythmic alteration in Baroque and partly Post-Baroque music. Beginning with the study by Arnold Dolmetsch who, in 1915 introduced into scholarly usage the lexeme conventional alteration of rhythm, many authorities have directed their scientific research toward the problem of the specific conventions which existed in rhythmic notation. As a result numerous related musical terms entered the thesaurus of contemporary research: 'conventional alteration of rhythm, 'rhythmic alteration', 'notes inégales', 'inequality', 'overdotting, 'unequal', and the like, which have become abundantly used. However, strict definitions and hierarchies among these terms are lacking in scholarly knowledge. Moreover, until the present day, one may uncover diametrically opposed and controversial interpretations of the basic concepts in the sphere of rhythmic alteration in thematically oriented music publications, reference and encyclopedic literature. The principal disagreements have arisen in connection with the French artistic technique of the notes inégales when a number of authors spread it far beyond the performance practice of French Baroque and Post-Baroque music contrary to, and without justification in, the opinions of early French musicians. This lead to great confusion in early music performance for those musicians who put much effort into their search for historically informed interpretation. The article attempts to reveal the most problematic aspects of modern ideas about the practice of rhythmic alteration in Western European music of the $17^{\text {th }}$ and $18^{\text {th }}$ centuries, and to point to the most characteristic and typological errors in the interpretation of historical sources by contemporary researchers.

Keywords: conventional alteration of rhythm, rhythmic alteration, notes inégales, inequality, overdotting, marqué, coulés, dont les points.

\footnotetext{
${ }^{1}$ The reported study was funded by RFBR according to the research project № 18-012-00208.

(c) Санкт-Петербургский государственный университет, 2018
} 


\begin{abstract}
"In order to know rightly the true meaning of the time signatures in regard to tempo, it would be necessary for all musicians to gather together, and in a general concert by means of a demonstration addressed to the eyes, or rather the ears of all, to come to an agreement [...] After that there would be no more ambiguity, at least not for those who had been present at the assembly [...] But this so useful concert being impossible to do, their meaning will always remain confused." 2
\end{abstract}

The situation outlined by de Saint Lambert in regard to early time signatures and tempo is in many points similar to the contemporary situation as it has evolved in the field of rhythmic alteration in general and in connection with notes inégales in particular. If such a discussion of the French notes inégales as recommended by de Saint Lambert could possibly take place in our time, the result would probably be even more substantially uncertain in comparison with the one cited above and recorded by de Saint Lambert, namely: "their meaning will always remain confused". For at the present time misleading interpretations expanded to an enormous size, and one constantly finds conflicting conclusions. Despite this, the present work will attempt to consider some selected issues associated with the original terminology in the field of notes inégales. Notwithstanding the great impact of the artistic gifts and scholarly abilities of Arnold Dolmetsch, and the overwhelming influence of his pioneer book on the twentieth-century "Early Music" movement which continues to be studied, this publication also opened a Pandora's box of new misunderstandings and misinterpretations. In our case it is related to misconceptions occurring in scholarly publications dedicated to "Early Music" performance practice dealing with rhythmic inequality ${ }^{3}$.

The logical reason for these originations lies firstly in the fact that Arnold Dolmetsch (as well as many other authors) had not given exact definitions of the terminology used in Chapter 3 "Conventional Alteration of Rhythm" of his book [3, p.54]; and, secondly, the book was host to many inadequate and even incorrect interpretations of historical source. Later, in the second half of the $20^{\text {th }}$ century, as in our time, we also will find in scholarly publications incorrect interpretations intermixed with many correct ones. In result, as Ido Abravaya [4, p.47] concluded, "so many examples and counter-examples were brought forth that the reader, baffled by the multitude of detail, might be inclined to think that everyone is right". In most cases these "many examples and counter-examples" occurred as a result of inconsistent and variable usage of special terminology.

Beginning the Section 1 of chapter 3 with the discussion of dotted figures Dolmetsch turns to the discussion of overdotting (based solely on Quantz's and C.P.E. Bach's treatises), then to the possible combinations of ternary figures with dotted ones, further to the so-called 'Lombard' rhythm with short-long interpretation of notes as being suitable for unequal performance of equally-written notes. The combination of ternary figures with quadruple and binary ones (written-out music structures) is discussed separately in Section 3, and lastly the vivid improvisatory ornamental practice of rhythmic alteration recommended by G. Caccini and other early musicians receives fully justification in Section $3[3, \text { p. } 71]^{4}$. Along with this Dolmetsch includes Frescobaldi's rhythmic innovations,

2 De Saint Lambert, Les Principes du Clavecin [1, p. 24], translated from: [2, p. 44].

3 The word "inequality" is used here to denote rhythmic alteration in its wide (general) sense, i. e. when notes written in equal time values are performed rhythmically unequal.

${ }^{4}$ One can find the same treating of the matter in David Tunley's book [5, pp. 14-5]. 
and further the French tradition of unequal rhythmic execution of even written notes by pairs (the latter were called by E. Borrel les notes inégales). After these excursuses into the problems of rhythmic alteration Dolmetsch returns to Quantz [47], namely to the very often cited in special music literature $\$ 12$ of chapter 11 where the explanation of possible changes of rhythm in evenly written notes becomes the main topic. Thus, among the aforementioned types of rhythmic alteration the Conventional Alteration of Rhythm or simply Alteration of Rhythm must be classified as a generalization concept, covering all forms of rhythmic changes in performing notes written even or uneven (dotted figures, 'Lombard' rhythm) by the composer, and which would not be accompanied by any special notational devices. Being thus determined, it would be reasonable to leave this scholarly term unchanged. However, later in the twentieth-century and in our time as well, the concept Alteration of Rhythm was interchangeably used with the term inequality (representing its synonym) which in its turn began to be understood also as the French inégalité. Consequently, this led to significant misinterpretations and to misunderstandings between authors writing on the subject of rhythmic alteration in early music.

The conclusion on the possibility of employing Alteration of Rhythm exemplified by Dolmetsch sounds very impressive: "we can but feel justified in treating all the old music alike in this respect" [3, p.62]. As a culmination of the main idea Dolmetsch offers one example among many others in his monograph and illustrates how his principle of alteration of rhythm should be realized, applying it to J. S. Bach's d minor Sarabande from the so-called French Suite (BWV 812) (Ex. 1):

The same Sarabande.

Proposed reading by A. D.

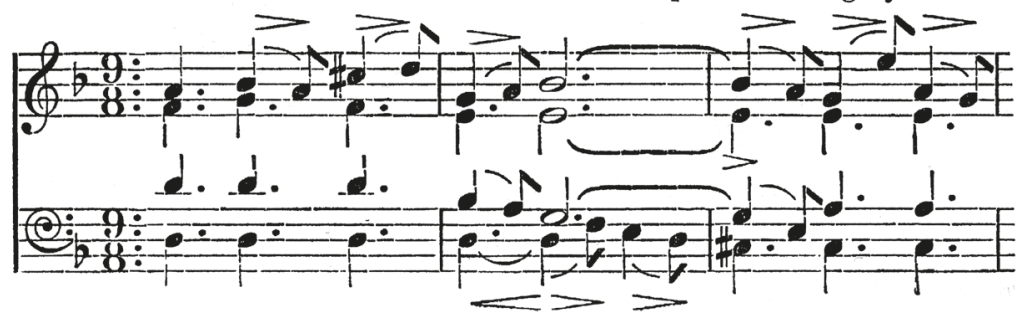

Example 1. J.S. Bach's d minor Sarabande (BWV 812)

Here the even-written eighth-notes in Bach's original text are recommended to be performed in a lilting rhythm of $2: 1$ by changing Bach's original meter from " $3 / 4$ " to " $9 / 8$ ".

In the beginning of the $20^{\text {th }}$ century Dolmetsch could not yet realize that his approach was historically and conceptually false; that even if he manifested a difference between some authors of the Berlin school (J. J. Quantz, J. F. Agricola) and C.P.E. Bach, D. G. Türk and others, the historical perspective built by him is highly questionable. Then again, notwithstanding that Dolmetsch's ideas were substantially and obviously refuted in Neumann's works, they gained persistent growth over nearly a hundred years, and as a result one may frequently find such ambiguous statements even as late as 2014, for example: "The French practiced notes inégales throughout the entire Baroque period, and Germans adopted it in the middle of the seventeenth century".

${ }^{5}$ See: [6, p. 113]. Practically the same idea — following Dolmetsch's recommendations — can be found in Jürgen Trinkewitz's guide to the historical harpsichord playing [7, pp. 147-54] and in Alice Peterson's 
Solely because of the above mentioned ambiguous treatment of the term "inequality", J. Byrt, for example, could exclaim "Finally, I shall never believe that inequality was essentially a French convention and would point to the fact that the earliest evidence we have for it comes from a Calvinist musician from Geneva (1550) and a Spanish writer on improvisation (1565). This is not to mention the writings on the subject by G. B. Bovicelli (1594), G. Caccini (1602) and G. Frescobaldi (1615) - Italians to a man. As to France's contribution - I side with Professor John Byrt, who writes that 'the French practice was a particular standardization of an existing, European-wide, ornamental practice"'. [9, p.555].

Even in the first part of this phrase it is impossible to understand some points, because two opposed categories are compared: "inequality" on the one side, which Byrt uses in his text as a term associated with a generalized manner of rhythmic alteration; and, on the other side, the scholar mentions the "French convention", which in its basic meaning is a localized and very specific stylistic phenomenon with its rules discussed in more than forty French treatises. If the French convention of notes inégales would be understood in a generalized form, then Byrt might confidently state that inequality was not essentially a French convention. But if the French convention represents an individualized form of rhythmic alteration (which is generally accepted by outstanding scholars), then this form of notes inégales should in fact be recognized as an "essentially a French convention". Believe it or not, this is the historical reality. Further, Byrt points to the "Calvinist musician from Geneva (1550)", thus, to Loys Bourgeois [10] who provides "the earliest evidence we have for it [i. e. for the French inequality]". Beginning from Eugène Borrel, Bourgeois's treatise is justly named as the first one where the French notes inégales are discussed $^{6}$. Next Byrt names Bovicelli, Caccini and Frescobaldi ("Italians to a man") with the earliest evidence on inequality. This latter "inequality" is of a very different type. As had been stated by Neumann the alteration of rhythm in the works of these Italian authors represents either "rubato-style rhythmic manupulations", or "short-long patterns in some specific cases of 16th notes (when they are combined with 8th notes)", or "dotted patterns ... dealing with diminutions [which] cannot be counted as belonging to the same category. They do not refer to unequal interpretation of equally-written notes [as the notes inégales], but to dotted patterns of improvised coloraturas..." [11, p.317]. So, as in Dolmetsch's book all categories of unequal notes in Byrt's phrase are mixed in an knot that cannot be untangled.

In this quotation Byrt also mentions the term "ornamental" used by John Butt. This term is treated still in a wider sense, because in Butt's studies [12;13] it embraces not only coloraturas, diminutions, compositional figures, rhetorical figures, embellishments, improvised ornamentation, European-wide, ornamental practice, etc., and now even rhythmic ornamentation. However, Butt does not give any exact definitions for these terms.

Next: what is the reason why Butt refused to treat the term diminution as it had been previously treated, namely, as precisely meaning an arbitrary inclusion of different music

thesis: "This [i. e. the "inequality"] was particularly a French practice, but not totally by any means (Caccini illustrates such a rhythm in his forward [sic.] to Le Nuove Musiche)." [8, p. 345]. Petersen understands the term "inequality" as notes inégales, and the latter is essentially a "French practice", but Caccini's rhythmic changes in this field belong to another aesthetic and artistic origin. The stylistic nature of Caccini's new approach in music performance expressed in the beginning of the $17^{\text {th }}$ century is completely different from the conventional tradition of notes inégales.

${ }^{6}$ See: [11, p. 317]. 
patterns of notes in shorter value instead of the written long ones. Thus, the problem of the frequent use of not authoritatively-settled terminology can be found in scholarly publications from 1915 to the present day.

Among the massive part of early materials in Dolmetsch's book which are presented as unquestionable arguments in favor of the new concept, there are some which demand validation. The first argument concerns a statement from Jean Rousseau's treatise Traité de Viole where, in the discussion of the Martellement, Dolmetsch [3, p. 72] sees a guideline for performing notes of even value unevenly. But on pp. 88-9 of Rousseau's Traité [14] there is not a hint of a rhythmically uneven performance of evenly written notes. Rousseau explains in detail on which note in different meters one should play mordents ("le Martellement") [15, p. 364]. Here this first argument is inappropriate.

Nontheless, Dolmetsch's idea was picked up later by other authors as a fully proven fact. For example, it is found even in Neumann's "Table II. Meter-Inequality Relationships..."7; next in St. Hefling's [19, p. 8] and D. Ponsford's [21, p. 31] charts. Roland Jackson [20, p. 199] first of all clearly equates the terms "inégalité" and "inequality" by stating at the very beginning of the part on uneven performance of even written notes: "Inequality [notes inégales] $\left(16^{\text {th }}-18^{\text {th }} \mathrm{c}\right.$.)" [all words in brackets in the quote above are Jackson's], but it seems somewhat uncommon to find out further that one of the "principal non-French writers to describe it [the inequality]" had been J.J. Quantz who, as Jackson says, was "transmitting an essentially French practice" ${ }^{8}$ Concerning J. Rousseau's explanations, Jackson is absolutely sure that "perhaps the first clear-cut description of the practice was provided by Rousseau (1687) [...]". Neumann bases his judgment on Rousseau's explanations of meter on p. 114 (instead of 88-89) understanding the word "marquer" in the expression "un peu marquer la premiere, troisième \& c, de chaque Mesure" and also in other phrases not as a term meaning metric emphasis, but as a term indicating rhythmic change. However, a detailed contextual study of the whole Chapter "One" of Part four from Rousseau's Traité shows that "marquer" is used in the sense of dynamics or articulation. Especially convincing is the next instruction: "[... ] il faut tirer les deux suivantes [notes] d'un seul coup, \& les marquer également [...]" "“[...] it is necessary to play the two following [notes] with one down-bow, and mark them equally [marked equally] [...]") [22, p. 113]. To prolong (marquer) a note in the inégal sense in Rousseau's recommendation and at the same time to try to play the same note as rhythmically equal leads to absurdity 9 .

Returning to Dolmetsch we see that in support of the previous claim, and as an additional argument he refers to the next subtle performance recommendation given by Fr. Couperin in his Des Explication des Agrémens, et des Signes: "Coulés, dont les points marquent que la Seconde note de Chaque tems doit être plus appuyée" (Premier Livre 1713), which has been quoted by some previous [24, p.104; 25, p.299] and many later

${ }^{7}$ As a substantiated fact the same is stated by E. Shay [16, p. 13] who included Rousseau's treatise among the first works, where "a description of notes inégales" is discussed and by Crockett [17, p. 257]. Fuller claims that "Jean Rousseau (1687) was perhaps the first to specify equal eighths and unequal sixteenths in C” [18, p. 25].

${ }^{8}$ Along with Quantz Jackson [20, p. 200] mentions Muffat (1698) whose instructions on inégalperformance, as it is known, almost exactly agree with the basic requirement of his time (1698).

${ }^{9}$ It is symptomatic that later Fuller [23, p. 191] expresses some hesitation concerning the presence of inégalité in Rousseau's tutor. Green, in his thesis [15] specially devoted to the study of Rousseau's treatises, however did not hesitate, and justly translated the word "marquer" as "accented". 
authors. At first sight there is nothing difficult in Couperin's guideline, but in it's completeness it is extremely hard to realize it in full. From Couperin's notated example and its explanation, a new pattern of SL inégalité was easily proclaimed (Dolmetsch, Donington, Hefling, and others).

Couperin provides the following often cited note-example with a verbal explanation of its performance (Ex. 2):

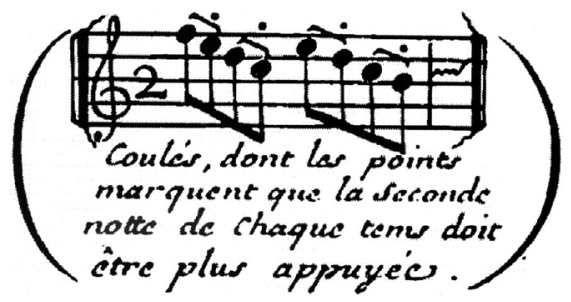

Example 2. Fr. Couperin. Pieces de Clavecin, Premier Livre. Paris, 1713, "Explication des Agrémens, et des Signes"

Dolmetsch's (and many others) realization reads:

Nobody recalled that Couperin had not written a single word saying that the first note of each pair should be rhythmically shortened. In fact, the first note is not even being mentioned by him. On the contrary: Couperin's concern is exclusively over the second note. The great French musician wants the performers to execute the second note of each slurred pair in consecutive ascending stepwise figures plus appuyée, i. e., holding the note more $^{10}$ (one might understand: till the very end of its duration, and not shortening it), Couperin indicates it by a dot printed over the end of each slur. R. Jackson and D. Tunley, contrary to Couperin's explanation, adhere to the Dolmetsch-Donington's one ${ }^{11}$.

For Couperin his explanation might have seemed compact and clear. To readers of the following generations its clearness became questionable, because it is not precisely certain which meaning Couperin had in mind when he used the polysemous terms coulés (coulées) and the wording plus appuyée. A careful examination of Couperin's indications (see below) even without a cross-checking shows that the latter are descriptive enough to obtain a convincing decision.

During more than a hundred and twenty years (c1895-2016), Couperin's very special performance devise received interpretations one opposing the other.

Finding answers to this question of terminology will be much more effective if we begin not with examining different external sources, as it is done by many authors, but if we consider Couperin's own instructions and study his vocabulary used in L'Art de toucher le Clavecin, in his Pièces de Clavecin, and in the Explication des Agrémens, et des Signes.

10 Thus, dwelling on it, as Donington clarifies in square brackets: “[literally 'leant upon']”. On the next line the eminent scholar explains that Couperin's wording means "notation indicating stress on the second note" and should be performed as: $[26$, p. 458].

11 "Couperin... did sometimes call the second note of a pair of 8ths that was joined by a slur with a dot above the second note as a note appuye, implying a short-long sequence" [20, p. 200]. Tunley concludes: "Finally, although Couperin makes no mention of notes inégales he includes the notation of quavers or eighth notes slurred in pairs with dots over the second of each, which in performance reverses the dotted rhythm of the usual inégales." [5, p. 107]. 
The term with the root derived from the verb couler is used by Couperin in three different meanings: in the sense of a one-note appoggiatura-like ornament [27, p.22], next for denoting a slide in the context of a third (a "flowing" or "sliding" ornament) (Tierce-coulée from Des Explication - 1713) ${ }^{12}$, and lastly as indicating slurs, or, to be more explicit, as slurred (legato) notes [27, pp. 29, 30,47]. Namely in the latter sense the word Coulés ("legato slurs") should be understood ${ }^{13}$, because otherwise it would mean that in Couperin's example the Coulés - if treated as appoggiaturas or slides - represent these patterns as ornamental structures written out in actual note-values, which in this certain context, is inconsistent ("an appoggiatura to another written-out in actual notes appoggiatura") ${ }^{14}$. Nowhere does Couperin even say that the Coulés could imply a rhythmic change in the initial note-values and be executed as a somewhat "jerky" 'Lombard' figure ${ }^{15}$. Instead, they are designed by Couperin to achieve an affect of beauty, effect of metric elegance and refinement. The artistic impact reached with their help, even (and especially) on a harpsichord can be very impressive with an inner exclusivity if, of course, one knows the performance technique and has the ability to convey the composer's idea.

The wording "plus appuyée" at first sight seems less uncertain, meaning "dwelling, holding"16. In treating the trill this term actually means to hold the upper auxiliary note before beginning the "batemens" [27, p. 24], just like (on the other side) "Tremblement lié sans etre appuye" in Couperin's Explication means: "A slurred trill without holding [without a noticeable preparation/holding of the upper auxiliary note]".

One should be especially alert in dealing with antiquated terminology. Stability of using and of understanding musical terms in early music theory and practice at that time had not been yet achieved, and discrepancies are met in many instances. Early authors most often used terms and their connotative meaning, which generally circled in their surroundings or were common to their own understanding. Illustrations can be numerous. The reader, for example, could be addressed to the term "l'Aspiretion" used in utterly different meanings by de Saint Lambert $\left(c 1697^{17} / 1702\right)$ and Fr. Couperin $(1716,1717)$. The substitution of any early polysemous term by another one in the course of an argument is very unreliable, and should be cautiously considered in every separate case. In our case it concerns the different usage of the words coulé and appuyée.

The interpretation of Coulés, dont les points in performance could be in our understanding approximately next:

${ }^{12}$ In Hefling's opinion [19, p. 166] "the term would seem to suggest a relation to French tierces coulées (descending thirds with an ornamental passing note between them)”. However, Couperin's notation 进 does not show organized "descending thirds", but on the contrary - groups of descending seconds.

${ }^{13}$ Neumann [11, p. 327] concludes that "The term Couler, 'to flow, signifies two things in the French musical literature of the time. First, it is simply the term for legato playing or singing [...]. Second, it is an agrément which 'flowingly' connects notes. The term is not used for the short-long playing of equallywritten notes. Couperin's directive 'Notes égales et coulées' in the Gavotte of the first Concert Royal, in the Forlane of the fourth Concert, or repeatedly in l'Apothéose de Corelli [...] would serve by itself to contradict such an assumption".

${ }^{14}$ Elizabeth Hays [28, p. 177] adheres to another point of view, and clarifies that these note-pairs might even be understood as "coulés [i. e., descending appoggiaturas] with slurs".

${ }^{15}$ Donington asserts that not only is the term "couler" used "sometimes" to denote "the snapped rhythm", but also that "a pair of notes slurred without dot can mean the same" [26, p. 454].

${ }^{16}$ Dolmetsch, later Hefling and other scholars treat Couperin's indication plus appuyée here in the rhythmic sense.

17 The approximate date of the first edition. See: $[29$, p. 427; 30, p. 32]. 


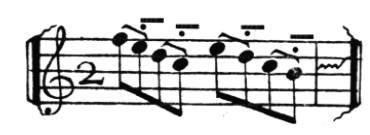

The argument concerning Couperin's Coulés, dont les points, which Dolmetsch puts forward to support his point of view on inequality in Jean Rousseau's treatise, is in result unreliable. But during the $20^{\text {th }}$ century and also in our time too advocates of Dolmetsch's and his predesessor's idea increased in number. This very specific performance device Coulés, dont les points is found very rarely even in Couperin's harpsichord music, and mostly in slow or moderate quick tempi what makes it unique ${ }^{18}$.

Proceeding further, we should reaffirm that our point of view is practically in complete agreement with Fr. Neumann's treatment of the Coulés, dont les points (despite the author's use of the word "emphasize" for Couperin's "appuyé") ${ }^{19}$. Neumann is disputing with Babitz and Donington over the treatment of this instruction. Neumann states: "What the caption [i. e. Couperin's direction] actually means is this: 'If the second of two slurred notes has a dot in it, this second note should be emphasized"' [11, p. 327]. In 1976 E. Hays theorizes on this matter, where she devotes much space to the examination of the wording plus appuyée. Couperin's words are justly translated by her as "more sustained [dwelled upon longer]". Further Hays uses Couperin's instruction as an opposition to C. P. E. Bach's recommendation on performing the same sign " - ". She clarifies: "the note under the dot is [on the contrary] curtailed rather than sustained [in Bach's instruction]" [28, p. 177; the text in square brackets by Hays].

In Bach's Versuch the first part of example "Fig. VI" is unfortunately not accompanied

$$
\text { trig: VI. }
$$

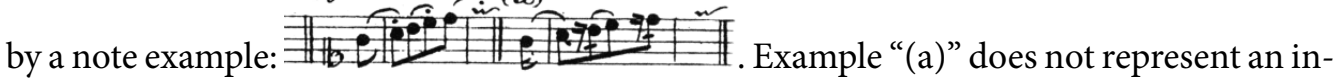
terpretation of Fig VI, it shows an erroneous interpretation which, as Bach says, the beginners often make. It is essentially important to note here that Bach is against shortening the first note of the slur. In playing he even wants it to be taken in such a manner that it would "produce a slight pressure" [32, Tab. VI]. The latter part of Bach's clarification (when it is compared with Couperin's) is most often omitted, because it contradicts the common practice of performing Couperin's Coulés, dont les points in our time and the mainstream opinion of many scholars who insist on shortening the first note of the slurred pair with a dot on the second note. Then again we fully realize that such a comparison is in its main parts inappropriate. Indeed, Couperin's and Bach's treatment of the dot at the end of the slur is diametrically opposed: Couperin asks to perform the second note "plus appuyée", and Bach recommends shortening it. One point remains immutable in the explanations of both musicians: the first note of the slurred pair must not be shortened.

Bach's principles and the French keyboard tradition were closely related. It is Bach who wrote: "there is a malicious prejudice against French keyboard pieces. These have

18 The "slur with a dot" is found in Couperin's harpsichord music only in his first (1713) and second (1717) books. One may assume that due to its exclusivity, and also to the possible misinterpretation of the "slur with a dot" by other harpsichordists as dots meaning staccato Couperin stopped writing it. It is noteworthy to emphasize that in Couperin's harpsichord music with more than 250 pieces only several have melodic passages which might recall the 'Lombard' rhythm. This attests that, in general, Couperin had no subjective preference for the 'Lombard' rhythmic figures in his music.

${ }^{19}$ Jean Saint-Arroman [31, pp. 336-7, 492] expressed the opposite point of view; i. e., the one which had been published as early as 1899 still by M. Seiffert [25, p. 299]. 
always been good schooling, for this country is sharply distinguished from others by its flowing and correct style." [33, p. 31].

Returning to Hays, it might seem that the author treats Couperin's and Bach's recommendation in the realm of articulation, but in the next nine pages of her dissertation all the available historic data is used to prove the presence of the rhythmic component in understanding the slur-with-dot figure.

In the sphere of performing harpsichord music Neumann [11, p. 327] leaves a possibility for "a short-long interpretation" of the indication -; and refers to the example showing the realization of Secondes coulées from Lart de facteur dorgues by Fr. Bédos de Celles [34, pl. cxi]. Some points need to be clarified. It is reasonable to examine Neumann's argument together with the expanded discussion of this exquisite matter by Collins, Hays and Hefling.

A closer inspection of the historic material (see Ex. 2) shows that Couperin's Coulés, dont les points and the Secondes coulées of Bédos de Celles are not exactly as identical as Neumann, Collins and Hefling regard them [11, p. 327; 35, p. 481; 19, pp. 14-5]. They are similar only in the initial part (Ex. 3).

a. As written:
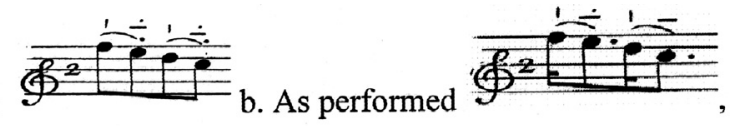

c. As notated for pinning the barel

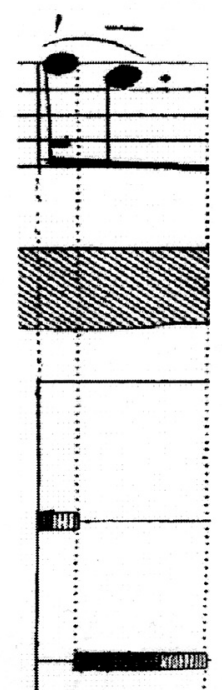

Example 3. Bédos de Celles (iv, 1778, Plate CXI): Secondes coulées

Contrary to Couperin's Coulés, dont les points the first note of each slurred pair in the Example 2a with Secondes coulées has a distinctly placed staccato sign above the first note, thus, performed in accordance with Marie-Dominique-Joseph Engramell's rules of Des Silences d'articulation; and, further, instead of holding (plus appuyée) the second note of the pair the latter is being articulatory shortened by not less than a third of its duration ( Ex. 3: a, b, c). Such a discrepancy between Couperin's and Engramelle's (Dom Bédos's) explanations should be taken earnestly in consideration. 
Next: Neumann turns to a new performance device indicated by a slur with a dot on the first note of each pair which had been in use by other musicians (c1741). As Neumann [11, p. 327] comments: "Dupuit [c. 1741] presents a pattern that is similar [with Couperin's] but has the dot on top of the first instead of the second of a pair of slurred notes which

he explains as short-longs:

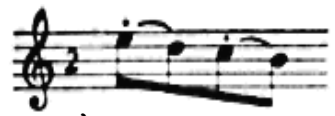

effet

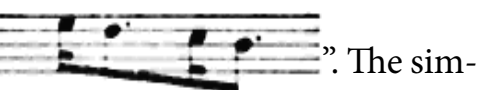
ilarity of Dupuit's and Couperin's patterns is very questionable, because in fact they pres-

ent an opposition. Furthermore, one may ask: how can opposed signs
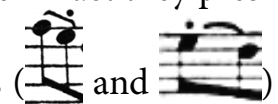
with dots placed on different notes receive the same interpretation? If considered carefully, the difference will be obvious: Dupuit shows a slurred pair of notes without any "silences

d'articulation" $=$ and Engramelle does so with a staccato sign: In sounding reality, as explained by Engramelle, the latter (see also above) is performed even with a rest after the eighth note ( $)$ by means of notation for pinning the barrel. Once again the arguments do not prove the similarity of Couperin's Coulés, dont les points with the examples and explanations of other musicians.

Nevertheless scholars continued trying to prove that Couperin's Coulés, dont les points and Engramell's Secondes coulées represented the same pattern and, hence, required the same interpretation. In the discussion of the Secondes coulées, Hefling, for example, refers to the Pièces de clavecin by P.-C. Foucquet (c. 1749/50) [36], which, he considers, might confirm his (and the mainstream) point of view. Hefling writes that Couperin's "unusual notational device ... was copied almost verbatim by Fouquet, without further explanation". "Almost verbatim" justly conveys the issue, but "almost" also means that something was different. What this small difference comprises can be seen in Ex. 4 given below:

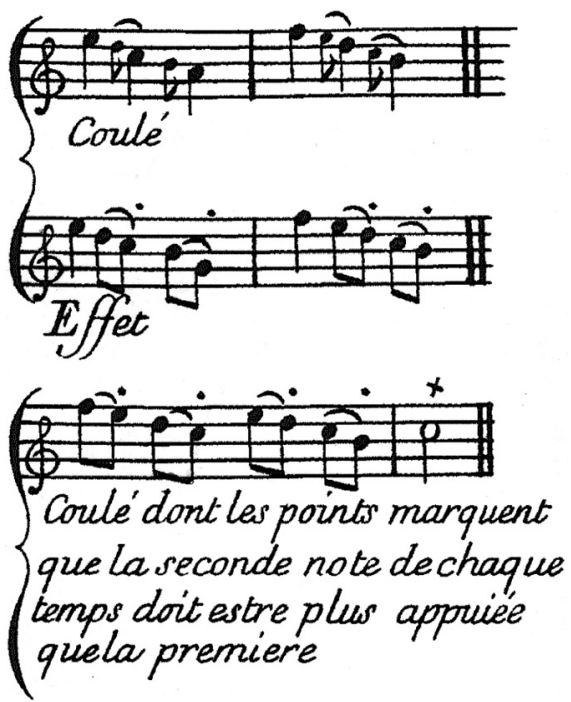

Example 4. P. -C. Foucquet. Les Caractures de la paix, [...] Paris, c1749/50, p. $6^{20}$

20 The absence of the second slur in the first bar is surely a typographical error. 
Hefling had not noticed several very important details (to be more exact, micro-details, but in studying early music the latter are often exceptionally significant). In the first line Foucquet is definitely not explaining the "Coulés, dont les points" which we treated earlier when Couperin's instruction was discussed. Foucquet is in fact showing how the

appoggiaturas ( pairs of slurred notes with a dot above the second note. Thus, the French authors treated the term Coule differently: Couperin understood the coulés as slurs, and Foucquet, for his part, treats them as appoggiaturas. It is namely the coulé (appoggiatura) which in Foucquet's opinion must be executed in the pattern of slurred pairs of notes with a dot at the end of each slur (see the second lines of Ex. 4). Then in the second line Foucquet shows how the notes should be interpreted (the third line). And lastly, the verbal explanation of the execution of note-patterns in line three follows. Foucquet's verbal explanation had actually been "verbatim" borrowed from Couperin, but Foucquet adds a very important detail at the end of the passage: "que la premiere" - "than the first" - by which he means that not only the second note should be performed appuyee, but that the first note should also be stressed, however less than the second note with the dot. Thus, according to Foucquet, the first note should not be modified in either way (contrary to Engramell's solution, and to today's mainstream concept). Both notes must be leant upon, but the second one still more. Not a word is said about rhythmic shortening or prolonging of any of the two notes. This explanation becomes still clearer when Foucquet places practically side by side two quite analogues patterns (darkened by us in Ex. 5) in the piece titled: "Marche des Pelerins de Cythere, Rondeau, Majestueusem ${ }^{t}$ sans lenteur. Les croches egales" (second book, our emphasis):

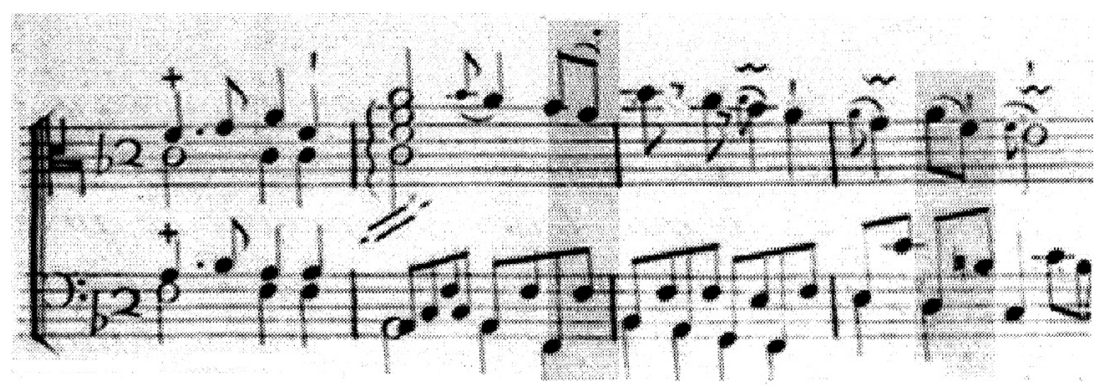

Example 5. P.-C. Foucquet. Second Livre de Piuces de Clavecin. Paris, c1750, p. 1

In the first pattern (Ex. 5, bar 2) the second note should be executed with an appuyée indicated by a dot. In the next pattern (Ex. 5, bar 4) Foucquet, on the contrary, recommends playing the second note articulately shortened (shown by a dash, in naming which Foucquet uses Couperin's term "Aspiration"). This opposition of expressive articulation would lose its sense if the first pattern were performed with a rhythmic change. Lastly, a rhythmic change would violate Foucquet's general requirement for this piece, i. e., "Les croches egales". Hefling unfortunately did not pay attention to the last words in Foucquet's explanation.

In contrast to the "jerky" manner of performing the Coulé (i.e. the upper appoggiatura) which is common today, Foucquet recommends a slurred and dwelled upon interpre- 
tation - According to Foucquet's verbal explanation, this last pattern is performed in such a manner that both notes are "dwelled upon", but especially the second one, and there is no rhythmic change in their performance.

Notation in the first 4 bars did not attract the needed attention of scholars. But it is interesting that such a variety of performance indications are used (see Ex. 5).

In result, a detailed study of historic evidence shows that the coherent system of $\mathrm{He}$ fling's argumentation is built upon an incomplete reading of the historical sources and on the difficulties associated with the interpretation of special musical terms used by Couperin and Foucquet.

Along with the "Methode" which was incorporated in the collection of harpsichord pieces by Foucquet, Hefling and earlier Hays tried to find new affirmation of their concept in Marpurg's theoretical works and in his music. As an argument Hefling points to an example from Marpurg's harpsichord pieces, and writes that the latter "uses the marking [i. e. "—."] once in his very French Pieces de clavecin (see Ex. 6)" [37; 19, p. 14].

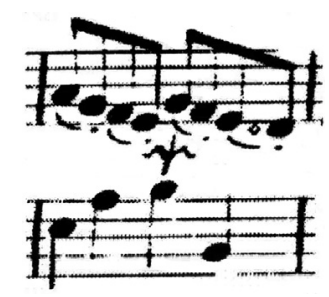

Example 6. F. W. Marpurg. Pieces de Clavecin.

"Les Remouleurs, gaiment, sans presser". Paris, c1747/48, p. 17

However, notwithstanding the copious amount of arguments, the issue even with the inclusion of materials from Marpurg's Pieces de Clavecin is far from being resolved ${ }^{21}$. On the contrary, a new problem arises which Hays and Hefling failed to notice: in Marpurg's French translation of his German treatise the author treats the wording zweyen geschleiften Noten as Deux notes coulées where it is absolutely clear that the French term coulé means slurred notes $[38$, p. 29; 39, p. 34]. This is exactly the meaning that contradicts the one shared by Hays and Hefling who understand the term coulées as used by Couperin and Foucquet as the French slides or appoggiaturas ${ }^{22}$.

Hefling disputes Neumann and writes "Neumann believes that Couperin's use of coul$e r$ in his short description of the slur-and-dot [thus, the Coulés, dont les points] 'refers to nothing but the slurred notes' [...] Yet the term would seem to suggest a relation to French tierces coulées (descending thirds with an ornamental passing note between them) [...]" $[19$, p. 166]. We have shown that Neumann did not err in his assertion when he believed that the slur-and-dot "refers to nothing but the slurred notes".

All such inconsistencies and contradictions arise due to the fact that there is no agreement on the use of terminology. Our current science resembles something like "Old Bab-

\footnotetext{
${ }^{21}$ In handling this matter Hefling follows the path outlined by Hays.

${ }^{22}$ Strictly speaking Couperin's Coulés, dont les points have nothing in common with the French conventional tradition of notes inégales, because the note-text is accompanied by indications for performance.
} 
ylon" where no one could understand each other, each having a personal point of view on everything, and not one even listening to the other's.

Returning to Dolmetsch and Quantz: Dolmetsch was, as Neumann states, the first musician to discuss in full the problems of rhythmic alteration in Quantz's treatise. After Dolmetsch, one meets very few authors on historically-informed performance of early music in our days who wouldn't have resorted to Quantz's famous treatise, and also to practically all his recommendations on rhythm. To be more exact, every passage or word from his work would have been scrutinized closely and thoroughly.

Current science in this field is dominated by two different concepts ${ }^{23}$ : the first in its main points follows Dolmetsch's all-embracing idea of total inequality and overdotting in performing early music without considering national specification and terminological distinction. Most characteristic within this concept is equating Quantz's instructions on alteration of rhythm with the French notes inégales. Babitz and Donington were among the first advocates of this concept [40; 41]. Similar assertions were published in later works, for example, D. Pyle who wrote: "Quantz also forbade notes inégales ${ }^{24}$ when the motion was too fast to make the notes unequal without awkwardness..." [42, p. 196].

The second group of scholars follow Neumann's opinion in its main points which challenges the principles of the previous authors and unravels the prevailing misconceptions. Debates over Quantz's explanations by contemporary scholars touch on a vast body of correlating matters leaving unaccented the theme concerning terminology mentioned above.

A special (but concise) consideration of Quantz's recommendations is necessary, because many authors in fact believe that the Berlin musician (as had been shown) suggests a detailed description of notes inégales. In the historic process the origin of Quantz's instructions on rhythmic alteration could be essentially based on the French phenomenon, but speaking of Berlin it should be kept in mind that there emerged, and began its growth, an impressive new musical and aesthetic viewpoint ${ }^{25}$. In this context it is necessary to return to this matter, and compare Quantz's explanations with the particular specifications of notes inégales ${ }^{26}$. It will be seen that the comparison reveals more divergences than similarities.

These characteristics were firstly considered by Babitz, then in part by Neumann and many other authors. In our time this problem is discussed by Beverly Jerold [45] who puts forward a new concept in interpreting Quantz's recommendations. The part of Jerold's paper titled as "The German 'good' and 'inferior' notes" directly begins by stating: "It is widely believed that a passage from Johann Joachim Quantz (1752) describes a system of note execution for Germany that parallels the French practice of notes inégales. Yet it contains parameters never encountered in French sources treating this form of note inequal-

${ }^{23}$ In this respect, space does not allow us to dig into the countless misinterpreted details as was done in the previous parts of this paper. There we tried to show that the incorrect interpretation of details which were deeply buried in the core of the historic evidence, subsequently lead to gross errors in the conception itself.

${ }^{24}$ It was already shown above that Quantz's consideration of the dynamic and rhythmic objects of music performance should not be characterized as the French "notes inégales", notwithstanding the fact that he (and the other Berlin musicians) were highly influenced by French (and also Italian) musicians.

${ }^{25}$ See C. P.E. Bach's Exempel nebst Achtzehn Probe=Stücken in sechs Sonaten, 1753 [43] - as practically all other of his Sonatas - stylistically are incomparable with most of the music written before c. 1740 .

${ }^{26}$ See our Essays: [44]. 
ity." This passage - contrary to today's 'mainstream' opinion - returns us to the historic reality of early music performance, but the further exploration of the theme leads Jerold to an exaggeration of the German system of metric emphasis, and as a result Quantz's main idea of rhythmical unequal interpretation of notes written in equal values, notwithstanding his important precaution: "[...] doch muss dieses Anhalten nicht soviel ausmachen, als wenn Puncte dabey stunden" - "but this holding must not be as much as if the notes were dotted [...]" is practically neglected ${ }^{27}$.

It is necessary now to summarize the deviations and to show once more that in Quantz's $\$ 12$ of chapter 11 there are basic differences which in many ways do not concur with the French notes inégales [47, pp. 105-6].

- Contrary to the French convention of notes ineégales, Quantz admits rhythmically unequal performance of notes written not in conjunct motion, as it becomes clear from the musical examples in his treatise (see: Tab. IX, Fig. 1).

- According to Quantz, the even - and odd - numbered note-pairs (i. e. the 'gute' and 'schlechte' notes in the terminology of that time), with slurs written over or under them, should be played rhythmically uneven; while in France, on the contrary, slurs placed over or under notes obligatorily indicate the necessity of playing these notes even, instead of a usually uneven (partly, or fully dotted) manner. This exception is described in many treatises of French musicians, and retains its significance throughout the $18^{\text {th }}$ century.

- The author of the treatise limits the practical application of the above-mentioned specific device of rhythmic alteration to the sphere of "pieces in moderate tempo" and to Adagio, while restrictions presented in such definitive terms are not found in French theoretical sources of that time.

- In addition to the rhythmical lengthening of each odd-numbered note (it might be a strong or relatively strong note in the framework of the metric structure in the "3/4" measure, thus "good") in a pattern or some other musical structure, Quantz in every case points to the necessity of somewhat stressing, or accentuating this note. In French treatises of that period in paragraphs dealing with notes inégales we will not locate requirements of this nature even in treatises devoted, like Quantz's, to the art of playing on the traverse flute ${ }^{28}$.

- In both passages from Quantz's Versuch, he is recommending a mild degree of unevenness in performing pair patterns of notes, and in both places Quantz especially points that this unevenness must not turn into a dotted rhythm. However, French musicians of the same historical period do not consistently mention such restrictions; moreover, a thorough study of their recommendations shows that to a greater extent a preference was given there to a sufficiently "strong" manner of dotting.

- Quantz's regulation is applied by him only to the " $3 / 2$ ", “3/4”, “3/8”, " $2 / 4$ ”, “ $₫$ ”, and "c" measures, and especially to pieces performed in slow, or moderate slow tempo; however in the field of performance practice, the special device of "unequal playing" in France in the $18^{\text {th }}$ century was more extensive.

${ }^{27}$ Cf. [47, p. 105]. See our counter-arguments: [46, p. 554].

${ }^{28}$ See, for instance: [48-52]. 
Therefore, Quantz's alteration of rhythm recommended to be used by modern performers has only a remote external similarity with the French notes inégales.

In a short paper it is impossible to give a description of all the inaccuracies and errors originating as a result of the imperfections of modern terminology related to the rhythmic alteration of the notated music text. The most important issues might be formulated as follows:

- In contemporary biblio- and reference encyclopedic literature there still are no precise definitions of the main concepts pertaining to the French notes inégales, to overdotting, underdotting, synchronization, the 'Lombard' rhythm, ornamental, among others. For example, D. Fuller - a recognized authoritative scholar in problems of conventional alteration of rhythm - not only does not give a precise definition of notes inégales in the article in The New Grove Dictionary, but even implicates overdotting in the concept, despite the opinion of most of the early French authors. Why is it that the meaning (understanding) of notes inégales in the $20^{\text {th }}$ and $21^{\text {th }}$ centuries suddenly began to be radically different from historical theory and practice? Why is it that the French musicians, according to Fuller, dotted the notes in their music, just not to observe the notated version, and in result wanted these same notes not to be performed as written but still more sharply dotted? The reader of this Grove article will see that its author often contradicts himself, for example, discussing the difficult problem of the French or non-French (supposedly generally European) origin of the notes inégales. Fuller also writes about notes inégales which stretched back "to the modal rhythms of the Middle Ages" and much further to the end of the article that notes inégales "reappear" in "American jazz". From this it follows that the concept of notes inégales extends to the unnotated music as well; i. e., to improvisation. A truly innovative idea ${ }^{29}$. It convinces us that in the next edition of The New Grove Dictionary we will find an integral concept of notes inégales which will include the interpretation of voodoo incantations.

- Underdotting (Germany, second half of the $18^{\text {th }}$ century). Why has no scholar studied this phenomenon? Indeed, following Fuller's logic, underdotting is also part of the notes inégales concept. But then, how is it that the French baroque authors had no knowledge of it, and we - have?

- The 'Lombard' rhythm: is it also a part of the French notes inégales convention?

- Special literature on notes inégales contains a vast array of different assertions, observations and expressions unraveled by just as many scholars from different countries. However, their cause is not identified: only the phenomenology is presented which gives minimum assistance to the performers. As Petersen suggested, "the reader must study them [all the historical details] for himself if he is to be able to make his own judgment, as he must do..." [8, pp. 344-5]. Just one example concerning the "reader" who does not know that, contrary to the contemporary "main stream" concept, de Montéclair after discussing the different time measures stated in his Petite méthode that "The sixteenth-notes are unequal in all kinds of measures" [54, p. 45, our emphasis]. Analogous instructions are found in Louliés treatise in the section on duple measures with two beats ("2", " 2 ", " $2 / 4$ ") where it is written: "The first and third quarters of each time are longer than the second and

${ }^{29}$ See also: [53, p. 20]. 
fourth, although they are marked equally, in whatever meter it be." [55, p. 32; 56, pp. 27-8]. The same expression is applied by Loulié to triple meters ("Dans quelque Mesure que ce soit"). As far as we know the instruction concerning the duple meters in Louliés work has not been thoroughly studied by scholars. No one has also pointed to the fact that further in his work Loulié diverges from his previous instruction, because he informs that in the measure " $2 / 4$ " the fourth parts of the beats should be taken as rhythmically uneven (thus the 16th notes). Despite this definition on p. 35 Loulié names the eighth-notes. This contradictory information is taken into account neither by Neumann [11, see Table on p. 322], Hefling [19, p. 8], nor by others, including Jerold [45, pp. 280-1; 57, p. 724] where the material on Loulié is often contradictory. At the origins of the incomplete study of Louliés treatise one may find Donington [26]. Thus, many scholarly statements need to be revised in connection with these previously unknown revelations.

- Is overdotting a form of notes inégales or it is something special? What are the true areal and chronological boundaries of this phenomenon? Based on the statements of several French musicians of the eighteenth century, Hefling and Fuller extend the technique of overdotting to all French music from c. 1650 to c. 1790.

- With respect to vocal coloraturas and diminutions, rhythmic ornamentation (J.Butt), and the like, do these terms receive their distinct definitions in the context of notes inégales? If they sometimes do, they nevertheless fully distort the meaning of the concept "ornamentation" of early musicians, and a terminological confusion arises in the environment of modern musicians. Another terminological problem emerges when Butt turns to Michael Prætorius's treatise [58, pp. 229-40]. Here is it not distinctly defined how the music figures enumerated by Butt and taken from Prætorius are related to ornamentation? Then (next) what is "ornamentation" and what is "ornamentic"? Where are the precise definitions of these terms? How are they related to the art of coloration and diminution?

- The confusion connected with early terminology has long been in a critical state, and is misleading for performers. Just one example: two practice-oriented manuals, published within a short period of time by reputable scientific publishers where in one of them Mark Kroll adheres to the idea that "Inégalité essentially remained within the borders of France. Composers of other nationalities were certainly aware of its existence, but it is dangerous to assume that it should be applied to their music unless these non-French composers indicated it specifically or were consciously writing in the French style." [59, p.268], and in the other one finds that Roland Jackson's opinion [20, p. 200] is quite the opposite: "inequality" [i. e. notes inégales] has the stylistic right to be used in interpreting foreign music, namely Handel's and J.S. Bach's. Hence, the performers, having read diametrically opposed, mutually exclusive recommendations, act according to their own understanding, moving away from stylistically correct manner in interpreting early music. More and more often one hears the voices of major performing musicians who (not without good reason!) teach their students that historians of theory, who themselves have little experience in performance on historical musical instruments and who very often are without a deep understanding in this very particular field, should themselves never be followed, and one should not incorporate their contradictory recommendations into performance. 
- Finally, why is there no hierarchically organized ontology of terms and concepts used in the sphere of notes inégales?

\section{Conclusion}

We will not be able to come to an agreement on the unification of the basic terms until an answer will be given to the main question: what was the purpose for early musicians of different countries and at different times to create a variety of conventions - from the simple (Bourgeois) to the rhythmically very complex ones (the French notes inégales), and also articulatory (accentuation - W.C. Printz, J. G. Walther, etc.) deviations from the regulations of the notated text. From our point of view, in most cases, at the head of everything stood His Majesty Tactus ${ }^{30}$. The analysis of the text and context of the numerous historical documents assures that the main task, which the early musicians tried to solve in this case, was strengthening the role of the metric structures in musical measure. In France this strengthening was achieved by rhythmical prolonging of the strong and relatively strong beats of the measure; in Germany by accentuating the strong beats and articulatory shortening of the sounding time for the weak notes (the "gute, bon" and "schlechte, mauvais" notes). In both instances the goal was the same but the means were different. After 1752, in Germany inégalité, inequality and also overdotting (in France occasionally, viz. J.Hotteterre) were introduced with the same purpose: to make the metrical structure of the composition more "prominent". And it is needless to say that in the sphere of art, and not only in music, each expressive technique engenders its antagonist. In our case, it is the free performance of the unmeasured preludes in France, and in Germany it is underdotting, especially in the second half of the $18^{\text {th }}$ century.

\section{References}

1. Saint Lambert de. Les Principes du Clavecin. Paris: Chr. Ballard, 1702.

2. Principles of the harpsichord by Monsieur de Saint Lambert. Translated and edited by Rebecca HarrisWarrick. Cambridge \& New York: Cambridge University Press, 1984.

3. Dolmetsch, Arnold. The Interpretation of the Music of the XVIIth and XVIIIth Centuries Revealed by Contemporary Evidence. London: Novello and Co.; New York: The H. W. Gray Co., n. d. [1915].

4. Abravaya, Ido. "A French Overture Revisited: Another Look at the Two Versions of BWV831"'. Early Music 25, no. 1 (1997): 47-61. doi:10.1093/earlyj/XXV.1.47

5. Tunley, David. François Couperin and 'The Perfection of Music'. Revised edition. London \& New York: Routledge, 2016.

6. Davis, Tony. "The Motets of George Philipp Telemann." DA diss., University of Southern California, 2014.

7. Trinkewitz, Jürgen. Historisches Cembalospiel: Ein Lehrwerk auf der Basis von Quellen des 16. bis 19. Jahrhunderts. Stuttgart: Carus, 2009.

8. Petersen, Alice Vanette Neff. "A Guide to the Development and Direction of an Early Music Performance Program." DA diss., Ball State University, 1980.

9. Byrt, John. “Correspondence." Early Music 43, no. 3 (2015): 555, doi:10.1093/em/cav066.

10. Bourgeois, Loys. Le droict chemin de musique. Geneva: [Jean Gérard], 1550.

11. Neumann, Frederick. “The French 'Inégales', Quantz, and Bach”. Journal of the American Musicological Society 18, no. 3 (1965): 313-58. doi:10.2307/830704.

12. Butt, John. Music Education and the Art of Performance in the German Baroque. Cambridge: Cambridge University Press, 1994.

${ }^{30}$ See: [60]. 
13. Butt, John. "Improvised Vocal Ornamentation and German Baroque Compositional Theory: An Approach to 'Historical' Performance Practice." Journal of the Royal Musical Association 116, no. 1 (1991): 41-62.

14. Rousseau, Jean. Traité de la viole. Paris: Chr. Ballard, 1687.

15. Green, Robert Anthony. "Annotated Translation and Commentary of the works of Jean Rousseau". PhD diss., Indiana University, 1979.

16. Shay, Edmund. "Notes Inégales and François Couperin's Messe a l'usage des Paroisses (Mass for the Parishes)". DMA diss., University of Cincinnati, 1969.

17. Crockett, Charlotte Gwen. "The Berlin flute sonatas of Johann Joachim Quantz" . PhD diss., The University of Texas at Austin, 1982.

18. Fuller, David. "Notes and inégales Unjoined: Defending a Definition”. The Journal of Musicology 7, no. 1 (1989): 21-8.

19. Hefling, Stephen E. Rhythmic Alteration in Seventeenth- and Eighteenth-Century Music: Notes Inégales and Overdotting. New York \& Toronto: Schirmer Books, 1993.

20. Jackson, Roland. Performance Practice: a dictionary-guide for musicians. London \& New York: Routledge, 2005.

21. Ponsford, David. French Organ Music in the Reign of Louis XIV. Cambridge: Cambridge University Press, 2011.

22. Rousseau, Jean. Méthode claire, certaine, et facile pour apprendre à chanter la musique. Paris: Chr. Ballard, 1678.

23. Fuller, David. "Notes inégales." In The New Grove Dictionary of Music and Musicians, edited by Stanley Sadie, 190-200. 2nd ed. New York, London, \&c.: Oxford University Press, 2001, vol. 18.

24. Dannreuther, Edward. Musical Ornamentation (Part I). London \& New York: Novello, Ewer and Co., n. d. [c1893].

25. Seiffert, Max. Geschichte der Klaviermusik. I. Band: Die ältere Geschichte bis um 1750. Leipzig: Breitkopf und Härtel, 1899.

26. Donington, Robert. The Interpretation of Early Music (New Revised Edition). New York \& London: W. W. Norton \& Co., 1992.

27. Couperin, François. L’Art de toucher le clavecin. Paris: L'Auteur, Boivin, 1717.

28. Hays, Elizabeth Loretta. "F. W. Marpurg's Anleitung zum Clavierspielen (Berlin, 1755) and Principes du Clavecin (Berlin, 1756)." PhD diss., Stanford University, 1977, vol. 2.

29. Panov, Alexei, and Ivan Rosanoff. "Sébastien de Brossard's Dictionnaire of 1701: A comparative analysis of the complete copy." Early Music 43, no. 3 (2015): 417-30, doi:10.1093/em/cav044.

30. Panov, Alexei, and Ivan Rosanoff. "De Saint Lambert and de Brossard: unknown and known". Vestnik of Saint-Petersburg University. Arts 2, no. 1 (2012): 28-44. Accessed July 04, 2017. https://cyberleninka. $\mathrm{ru} / \mathrm{article} / \mathrm{v} /$ neizvestnye-izvestnye-de-sen-lamber-i-de-bross-ar. (In Russian)

31. Saint-Arroman, Jean. L'Interprétation de la Musique Française 1661-1789. Volume 1. Dictionnaire d'interpretation. Paris: Honoré Champion, 1983.

32. Bach, Carl Philipp Emanuel. Versuch über die wahre Art das Clavier zu spielen. Berlin: der Autor, 1753.

33. Bach, Carl Philipp Emanuel. Essay on the True Art of Playing Keyboard Instruments. Translated and edited by William J. Mitchell. London: W. W. Norton \& Co., 1948.

34. Bédos de Celles, Dom François. L’art de facteur d’orgues. Paris: Desaint, Saillant \& Nyon, 1766-1778), t. 4 .

35. Collins, Michael. "Notes inégales": A Re-Examination." Journal of the American Musicological Society 20, no. 3 (1967): 481-5. doi:10.2307/830324.

36. Foucquet, Pierre-Claude. Les caractéres de la paix, pieces de clavecin. Paris: L'Auteur et d'autres, Lion: de Bretonne, n. d. [c1751/52].

37. Marpurg, Friedrich Wilhelm. Pieces de Clavecin. Paris: Le Clerc et d'autres, n. d. [c1747/48].

38. Marpurg, Friedrich Wilhelm. Anleitung zum Clavierspielen. Berlin: A. Haude \& J. C. Spener, 1755.

39. Marpurg, Friedrich Wilhelm. Principes du Clavecin. Berlin: A. Haude \& J. C. Spener, 1756.

40. Babitz, Sol. "A Problem of Rhythm in Baroque Music." The Musical Quarterly 38, no. 4 (1952): 533-65.

41. Donington, Robert. "Inégales (Notes)." In Grove’s Dictionary of Music and Musicians, edited by Eric Blom, 477-82. 5th ed. New York: Macmillan, 1954, vol. 4.

42. Pyle, Daniel Sherman. "Nicolas Gigault's Livre de Musique Pour L'Orgue as a Source on Notes Inégales." PhD Diss., University of Rochester, 1991. 
43. Bach, Carl Philipp Emanuel. Exempel nebst Achtzehn Probe=Stücken in sechs Sonaten zu Carl Philipp Emanuel Bachs Versuche über die wahre Art das Clavier zu spielen auf XXVI. Kupfer=Tafeln. Berlin: der Autor, 1753.

44. Rosanoff, Ivan, and Alexei Panov. Essays on Problems of Rhythm in Germany in the XVIIIth Century: Overdotting and the So-Called Taktenlehre (a research of sources). Heilbronn: Musik-Edition Lucie Galland, 1996.

45. Jerold, Beverly. "Notes inégales: a definitive new parameter." Early Music 42, no. 2 (2014): 273-89, doi:10.1093/em/cau029.

46. Panov, Alexei, and Ivan Rosanoff. "Correspondence." Early Music 43, no. 3 (2015): 553-5, doi:10.1093/ em/cav067.

47. Quantz, Johann Joachim. Versuch einer Anweisung die Flute traversiere zu spielen. Berlin: Johann Friedrich Voß, 1752.

48. Hotteterre, Jacques-Martin. Principes de la Flute traversiere, ou Flute D’Allemagne; de la Flute A Bec, ou Flute Douce; et du Haut-Bois. Paris: Chr. Ballard, 1707.

49. Hotteterre, Jacques-Martin. L'Art de Preluder sur la Flûte Traversiere sur la Flûte a bec, Sur le Haubois, et autres Instrumens de Deßus. Paris: L'Auteur, 1719.

50. Corrette, Michel. Méthode Raisonnée pour apprendre aisément a jouër de la Flûtte Traversiere avec les principes de Musique, des Ariettes et autres Jolis Airs en Duo. Paris: Boivin, n. d., [c1740].

51. Bordet, Toussaint. Méthode Raisonnée Pour apprendre la Musique d'une façon plus claire et plus précise a laquelle on joint létendue de la Flute traversiére, du Violon, du Pardessus de Vielle et de la Musette [...] Paris: l'Auteur, Bayle; Lion: Bretonne, n. d. [c1755/57].

52. Mussard. Nouveaux Principes Pour apprendre a jouer de la Flutte Traversiere. Paris: l'Auteur, n. d., [c1778/79].

53. Veilhan, Jean-Claude. Les Régles de l'Interprétation Musicale à l'Époque Baroque (XVIIe-XVIIIe s.) générales à tous les instruments. Deuxième édition. Paris: Leduc, 1977.

54. Montéclair, Michel Pignolet de. Petite Méthode Pour apprendre la Musique aux Enfans et même aux Personnes plus avancées en âge. Paris: Boivin, n. d. [c1736/37].

55. Loulié, Étienne. Elements ou principes de musique, Mis dans un nouvel Ordre. Paris: Chr. Ballard, 1696.

56. Étienne Loulié. Elements or Principles of Music. Translated by Albert Cohen. New York: Institute of Mediaeval music, n. d. [1965].

57. Jerold, Beverly. "A reply to Alexei Panov, Ivan Rosanoff and John Byrt". Early Music 43, no. 4 (2015): 723-5, doi:10.1093/em/cav092.

58. Praetorius, Michael. Syntagmatis Musici [...] Tomus Tertius. Wolfenbüttel: Elias Holwein, 1619.

59. Kroll, Mark. "Keyboard Instruments". In Kite-Powell, Jeffery. A Performer's Guide to Seventeenth-Century Music, edited by Stewart Carter, 248-71. Bloomington \& Indianapolis: Indiana University Press, 2012.

60. Panov, Alexei, and Ivan Rosanoff. "Towards the Tact and Tactus in German Baroque Treatises". Musiqi dünyası, no. 3/60 (2014): 7157-80. Accessed July 04, 2017. http://www.musigi-dunya.az/pdf/60/2.pdf.

Received: 20.01.2018

Accepted: 28.02.2018

Author's information:

Alexei A. Panov - Dr. Habil.; a.panov@spbu.ru

Ivan V. Rosanoff - Dr. Habil.; irosanoff@yandex.ru 